\title{
CYCLITOLS, GALACTOSYL CYCLITOLS AND RAFFINOSE FAMILY OLIGOSACCHARIDES IN MEXICAN WILD LUPIN SEEDS
}

\author{
AgNiesZKa I. PiotrowiCZ-CIEŚLAK ${ }^{1}$, \\ PEDRO MACEDONIO GRACIA LOPEZ ${ }^{2}$, KRZYSZTOF GULEWICZ ${ }^{3}$ \\ ${ }^{1}$ Department of Plant Physiology and Biotechnology \\ University of Warmia and Masuria \\ pl. Łódzki 3, 10-718 Olsztyn, Poland \\ ${ }^{2}$ Departamento de Botanica y Zoologia Universidad de Guadalajara \\ Mexico 45-100 Gualadajara Km 14.5 Carretera Gualadajara Nogales \\ Las Agujas Nextipac 6820003 \\ ${ }^{3}$ Institute of Bioorganic Chemistry PAS \\ Noskowskiego 12, 61-704 Poznan, Poland
}

(Received: August 22, 2002. Accepted: March 20, 2003)

\begin{abstract}
Ten to 16 ethanol-soluble carbohydrate components were identified in the seeds of six Mexican wild lupins. The analysed carbohydrates included: monosaccharides, disaccharides, cyclitols, galactosyl cyclitols and raffinose family oligosaccharides. Stachyose and sucrose were the main carbohydrate component in the Lupinus montanus, L. rotundiflorus, L. exaltatus, L. mexicanus and L. elegans seeds. Only trace quantities of verbascose were detected in Lupinus mexicanus seeds. The analysed seeds accumulated 38 to $78 \mathrm{mg} / \mathrm{g} \mathrm{d} . \mathrm{m}$. carbohydrates. The raffinose family oligosaccharides constituted 41 to $85.2 \%$ of the identified carbohydrate component pool. The analysed $\mathrm{Lu}$ pinus seeds contained 3 to 8 unidentified carbohydrate components.
\end{abstract}

KEY WORDS: wild lupin seeds, carbohydrates, raffinose family oligosaccharides, galactosyl cyclitols, cyclitols.

\section{INTRODUCTION}

Lupins belong to the family of Leguminosae and the sub-family of Papilionoideae. They include about 300 species that, in the scientific literature, are referred to by over 2000 synonyms (Gladstones 1998). Natural habitats for lupins are located in two centres: the western American coast stretching from Alaska to Argentina and the Mediterranean Sea basin stretching to the central Africa. Lupinus albus, Lupinus luteus and Lupinus angustifolius are the most common cultivars originating from the Mediterranean Sea basin. However, the majority (270 species) of lupins are wildly growing in both Americas. Among such great number of species only one, Lupnus mutabilis, was grown as a crop, however, was forgotten with the collapse of the Incas empire. Lupine was cultivated even in the pre-Columbian times in Bolivia, Peru and Ecuador. Lupinus consenti$n i$ originating from the Mediterranean Basin and the Western coast of Australia has also been domesticated. Currently, crop scientists have made significant progress into domesticating two lupine species: Lupinus pilosus and $\mathrm{Lu}$ pinus atlanticus (Buirchell and Cowling 1992). Due to the- ir high nutritive value, interest in lupins has been increasing both in Latin America and Europe. Lupin crops, as well as wild lupins, have great concentrations of protein and fats (Petterson et al. 1994). Generative part of lupins are rich source of soluble carbohydrates, which are presented mainly by sucrose and $\alpha$-D-galactosides of sucrose and cyclitols (Górecki et al. 1997b; Muzquiz et al. 1999). These carbohydrates includes: raffinose family oligosaccharides (RFO) - raffinose, stachyose and verbascose and galactosyl cyclitols. The structures of these carbohydrates, especially RFO, are well know and described in literature (Dey 1985; Arentoft and Sörensen 1992; Horbowicz and Obendorf 1994; Hedley 2000).

From the nutritional point of view RFOs are considered as antinutritional factors (Cristofaro et al. 1974; Saini and Gladstones 1986). In the last years these compounds are object of increasing interest of nutritionists as a prebiotics - modifying the composition of colon bacterial microflora (Tomomatsu 1994; Loo et al. 1997; Gulewicz et al. 2000).

RFOs perform very important a protective physiological functions (Larsson et al. 1993; Horbowicz and Obendorf 1994; Górecki et al. 1997a). The knowledge concerning 
function of galactosyl cyclitols in plants is rather fragmentary. It is supposed that these compounds play similar function like RFOs. The metabolism of both group of $\alpha$-galactosides is so far small know. The main cause of weak progress in studies on biosynthesis of RFOs and galactosyl cyclitols is lack suitable experimental material. Up to now biosynthesis studies were carried out mainly on domesticated legume varieties which contain mainly RFOs, when galactosyl cyclitols content is repeatedly lower. In this respect the content both these carbohydrates in wide form is whereas small know.

The aim of this paper was to determine the qualitative and quantitative carbohydrate composition in the seeds of six wildly growing Mexican lupins.

\section{MATERIAL AND METHODS}

The seeds of Lupinus montanus, Lupinus rotundiflorus, Lupinus exaltatus, Lupinus mexicanus, Lupinus madrensis,
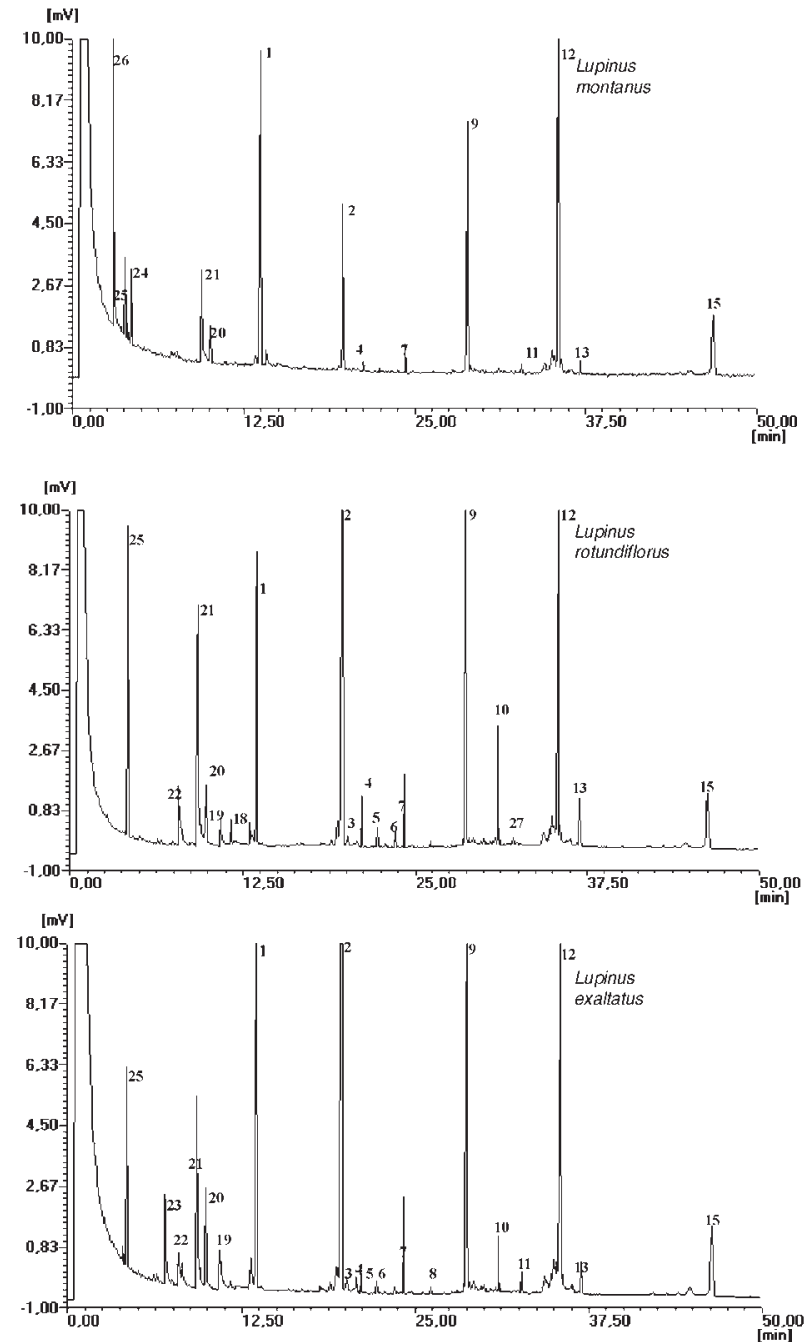

and Lupinus elegans were collected in region of Guadalajara-Mexico.

Soluble sugars were analysed according to Horbowicz and Obendorf (1994) with slight modification.

$100 \mathrm{~g}$ of seeds were ground, of which $30 \mathrm{mg}$ of tissue samples were taken for further analyses. Tissues, $30 \mathrm{mg}$ of seeds were homogenised in ethanol: water, 1:1 (v/v) containing $100 \mu \mathrm{g}$ phenyl- $\alpha$-D-glucose as the internal standard (Horbowicz and Obendorf 1994). The homogenate and the rinse were combined in a $1.5-\mathrm{ml}$ microfuge tube, heated at $75^{\circ} \mathrm{C}$ for $30 \mathrm{~min}$ to inactivate endogenous enzymes and centrifuged in a centrifuge MPW-365 (Poland) at $15000 \mathrm{~g}$ for $20 \mathrm{~min}$. The supernatant was passed through a $10000 \mathrm{MW}$ cut-off filter (Lida, Kenosha, WI, USA). Aliquots of $0.5 \mathrm{ml}$ filtrate were transferred to silylation vials and evaporated to dryness under a stream of nitrogen. Residues were kept overnight in a dessicator, over phosphorus pentoxide. Dry residues were derivatised with $300 \mu$ of silyation mixture (trimethylsilylimidazole: pyridine, $1: 1, \mathrm{v} / \mathrm{v}$ ) in silylation vials (Supelco) at $70^{\circ} \mathrm{C}$ for $30 \mathrm{~min}$ and then cooled at room
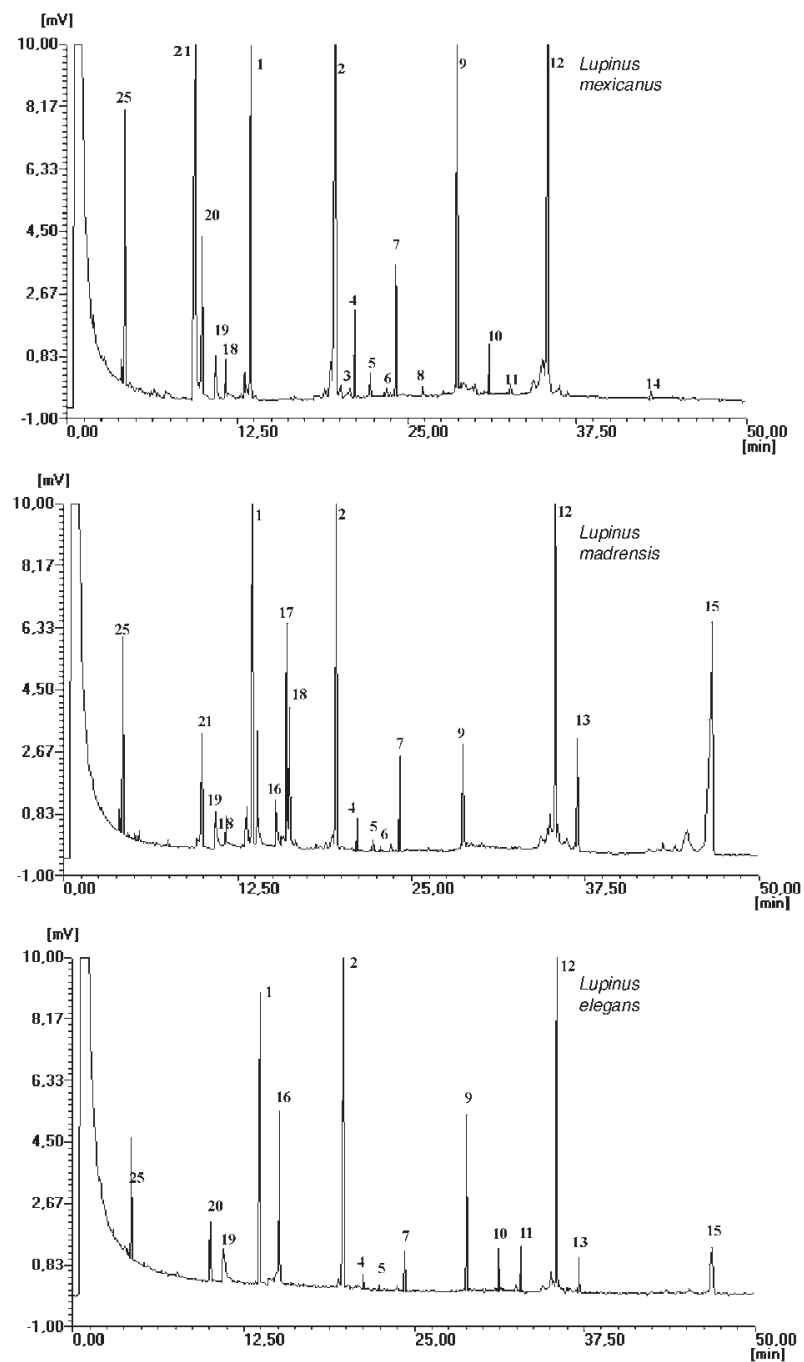

Fig. 1. Chromatograms of soluble carbohydrates isolated from Mexican Lupinus seeds.

Peaks: 1 - internal standard; 2 - sucrose; 3 - unknown; 4 - galactopinitol A; 5 - galactopinitol B; 6 - fagopyritol B1; 7 - galactinol; 8 - unknown; 9 - raffinose; 10 - ciceritol; 11 - digalacto-myo-inositol; 12 - stachyose; 13 - trigalactopinitol A; 14 - unknown; 15 - verbascose; 16 - unknown; 17 - unknown; 18 - unknown; 19 - unknown; 20 - unknown; 21 - myo-inositol; 22 - unknown; 23 - D-chiro-inositol; 24 - fructose; 25 - D-pinitol; 26 - unknown; 27 fagopyritol B2. 
temperature. One $\mu$ of derivatised soluble carbohydrate was injected into a split-mode injector of a Hawlett Packard 5890 Series II or Shimadzu GC-14A gas chromatograph equipped with flame ionisation detector and Hewlett Packard 3396 or Shimadzu C-R6A integrator. Soluble carbohydrates were analysed on a DB-1 capillary column (15 $\mathrm{m}$ length, $0.25 \mathrm{~mm}$ ID, and $0.25 \mu \mathrm{l}$ film thickness, J\&W Scientific) operated with a programmed initial temperature of $150^{\circ} \mathrm{C}$, adjusted to $200^{\circ} \mathrm{C}$ at $3^{\circ} \mathrm{C} / \mathrm{min}$, adjusted to $325^{\circ} \mathrm{C}$ at $7^{\circ} \mathrm{C} / \mathrm{min}$, and held at $325^{\circ} \mathrm{C}$ for $40 \mathrm{~min}$. The injector port was at $335^{\circ} \mathrm{C}$ and the detector at $350^{\circ} \mathrm{C}$. The carrier gas was helium at $3 \mathrm{ml} / \mathrm{min}$, split 1:50 and the detector gas hydrogen at $30 \mathrm{ml} / \mathrm{min}$ and air at $300 \mathrm{ml} / \mathrm{min}$. Soluble carbohydrates were identified with intermediate standards as available and calculated from the ratios of the area of peaks for each known carbohydrate to the area of peak for the internal standard.

Quantities of soluble carbohydrates are expressed as mean \pm SE of the mean for 5-7 replications of each treatment.

\section{RESULTS AND DISCUSSION}

Sixteen known carbohydrate components were identified in the analysed seeds and they included: monosaccharides, disaccharides, cyclitols, galactosyl cyclitols and raffinose family oligosaccharides. Besides these, the analysed seeds included from 3 to 8 unknown carbohydrate compounds. Chromatograms profile are plotted in figure 1 . The greatest number of unknown compounds was found in Lupinus montanus and Lupinus madrensis, whereas the least number was found in the seeds of Lupinus elegans.

\section{Raffinose family oligosaccharides}

The seeds of wild lupin contain from 2.3 to $3.6 \%$ of raffinose family oligosaccharides (RFO) including raffinose, stachyose and verbascose. Stachyose was found to be the major carbohydrate in Lupinus rotundiflorus, and L. mexicanus seeds (22.06 and $20.41 \mathrm{mg} / \mathrm{g} \mathrm{d.m}$. respectively). Raffinose, however, constituted 0.8 to $8.83 \mathrm{mg} / \mathrm{g} \mathrm{d} . \mathrm{m}$. in $L$. madrensis and L. mexicanus, respectively. Also the amount of verbascose in the analysed seeds varied. The seeds of $L$. madrensis contained the greatest amounts of verbascose, whereas those of L. mexicanus had only its residues and constituted 26.83 and $0.02 \mathrm{mg} / \mathrm{g}$ d.m., respectively. The domesticated lupins such as Lupinus albus, L. luteus and $L$. angustifolius contain significantly greater amounts of RFO components. From among the cultivated lupin species, it is the yellow lupine seeds which accumulate the largest amounts of raffinose family oligosaccharides (RFO). The concentration of RFO in yellow lupin seeds ranges from 50 to $110 \mathrm{mg} / \mathrm{g} \mathrm{d.m}$. depending on the variety (Piotrowicz-Cieślak et al. 1999). Moreover, the seeds of the cultivated species always contain 2-3 times more RFO in the embryonic axes than in the cotyledons. Humidity and temperature during seed maturation are the factor which particularly modify the content of RFO. The lupin seeds cultivated at a temperature of $15^{\circ} \mathrm{C}$ have $30 \%$ greater level of RFO than the seeds cultivated at $28^{\circ} \mathrm{C}$ (Piotrowicz-Cieślak 2002). An increase in the intensity of RFO accumulation was also observed in the seeds of Vicia hirsuta subject to water stress. The chemical composition of seeds, although it is determined genetically, may be strongly modified by a wide varie- ty of environmental factors. An increased accumulation of RFO was observed in the seeds subject to natural or forced desiccation (Lahuta et al. 2002).

The seeds of all the crop lupins, among all the carbohydrates, contain stachyose in the largest amounts. A greater concentration of RFO in the embryonic axes than in the cotyledons was found in all the seeds of the analysed lupin species (Górecki et al. 1997a).

The carbohydrate composition in the seeds of different plant species has been described by Kuo et al. (1988). Such analyses were also completed for the legume seeds such as lentils (Frias et al. 1996), pea (Kvasnička et al. 1994; Harrison 1996), soybean (Lowell and Kuo 1989) and lupins (Piotrowicz-Cieślak et al. 1998; Muzquiz et al. 1999). The reported differences in the carbohydrate compositions resulted from differences between lines, species or varieties.

The sucrose and raffinose family oligosaccharide content in the seeds may determine and indicate their storing capacity. The sucrose to RFO ratio, specifically, reflects seeds storing capacity (Horbowicz and Obendorf 1994). Seeds with the ratio value below 1 can be stored longer than 10 years. The greatest storage capacity was found for the seeds of Lupinus montanus with the ratio below 0.09. They naturally grow on heights of over $3500 \mathrm{~m}$ above see level, require sandy soil on meadows among Pinus hartwegii forests and flower between December and January. Among the lupins, this species grows in the toughest soil and climatic conditions and this undoubtedly contributes to their great capability of adaptation and storage.

\section{Galactosyl cyclitols}

Galactosyl cyclitols are also present in all lupin seeds (Piotrowicz-Cieślak and Górecki 2000; Piotrowicz-Cieślak et al. 1999). In the wild lupin seeds, four compound series were separated including the known carbohydrates:

I myo-inositol fraction

- galactinol (0- $\alpha$-D-galactopyranosyl- $(1 \rightarrow 3)$-D-myo-inositol), digalacto-myo-inositol (0- $\alpha$-D-galactopyranosyl$(1 \rightarrow 6)-0-\alpha-D$-galactopyranosyl-( $1 \rightarrow 2)-D-m y o-$ inositol);

II pinitol A fraction - galactopinitol A $(0-\alpha-\mathrm{D}$-galactopyranosyl-(1 $\rightarrow 2)-4-0$-methyl-D-chiro-0-inositol), ciceritol (0- $\alpha$-D-galactopyranosyl-( $1 \rightarrow 6)-0$ - $\alpha$-D-galactopyranosyl-(1 $\rightarrow 2)-4-0$-methyl-D-chiro-inositol), trigalactopinitol A (0- $\alpha$-D-galactopyranosyl-( $1 \rightarrow 6)-0$ - $\alpha$-D-galactopyranosyl$(1 \rightarrow 6)-0-\alpha-D$-galactopyranosyl- $(1 \rightarrow 2)-4-0$-methyl-D-chiroinositol);

III pinitol B fraction

- galactopinitol B (fagopyritol A1, 0- $\alpha$-D-galactopyranosyl-(1 $\rightarrow 2)-3-0$-methyl-D-chiro-inositol), digalactopinitol B (0- $\alpha$-D-galactopyranosyl- $(1 \rightarrow 6)-0-\alpha-D$-galactopyranosyl-(1 $\rightarrow 2)-3-0$-methyl-D-chiro-inositol);

IV chiro-inositol fraction

- galacto-chiro-inositol (fagopyritol B1, 0- $\alpha$-D-galactopyranosyl-( $1 \rightarrow 2)$-D-chiro-inositol), digalacto-chiro-inositol (fagopyritol B2, 0- $\alpha$-D-galactopyranosyl- $(1 \rightarrow 6)-0-\alpha-$ -D-galactopyranosyl-(1 $\rightarrow 2)$-D-chiro-inositol), trigalactopinitol B (0- $\alpha$-D-galactopyranosyl- $(1 \rightarrow 6)-0-\alpha$-D-galactopy-

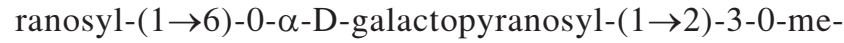
thyl-D-chiro-inositol).

The seeds of wild lupins such as Lupinus montanus and Lupinus hildego accumulate 2.47 to $9.93 \mathrm{mg} / \mathrm{g} \mathrm{d} . \mathrm{m}$. of galactosyl cyclitols, respectively. These seeds accumulated the greatest amounts of ciceritol and trigalactopinitol A. 
TABLE 1. Carbohydrates composition in the seeds of six wildly growing Mexican lupins [mg per g d.m. seeds] (data are the means of 5-7 replications of each treatment \pm standard deviation).

\begin{tabular}{|c|c|c|c|c|c|c|}
\hline Soluble carbohydrates & L. montanus & L. rotundiflorus & L. exaltatus & L. mexicanus & L. madrensis & L. elegans \\
\hline Glucose & $0 \pm 0$ & $0 \pm 0$ & $0 \pm 0$ & $0 \pm 0$ & $0 \pm 0$ & $0 \pm 0$ \\
\hline Galactose & $0 \pm 0$ & $0 \pm 0$ & $0 \pm 0$ & $0 \pm 0$ & $0 \pm 0$ & $0 \pm 0$ \\
\hline Fructose & $0.38 \pm 0.01$ & $0.14 \pm 0.01$ & $0.12 \pm 0.05$ & $0.17 \pm 0.02$ & $0.27 \pm 0.23$ & $0.60 \pm 0.04$ \\
\hline \multirow[t]{2}{*}{ Sucrose } & $2.67 \pm 0.04$ & $25.21 \pm 0.01$ & $24.55 \pm 0.97$ & $22.39 \pm 2.19$ & $34.43 \pm 2.23$ & $6.75 \pm 0.98$ \\
\hline & \multicolumn{6}{|c|}{ Cyclitols } \\
\hline D-pinitol & $1.43 \pm 0.08$ & $6.59 \pm 0.23$ & $2.44 \pm 0.45$ & $3.83 \pm 0.23$ & $2.00 \pm 0.15$ & $1.05 \pm 0.02$ \\
\hline D-chiro-inositol & $0.54 \pm 0.03$ & $0 \pm 0$ & $1.62 \pm 0.54$ & $0 \pm 0$ & $0 \pm 0$ & $0 \pm 0$ \\
\hline \multirow[t]{2}{*}{ myo-inositol } & $1.25 \pm 0.15$ & $1.10 \pm 0.28$ & $1.19 \pm 0.04$ & $3.07 \pm 0.56$ & $1.68 \pm 0.56$ & $1.22 \pm 0.24$ \\
\hline & \multicolumn{6}{|c|}{ Galactosyl cyclitols } \\
\hline Galactopinitol A & $0.18 \pm 0.07$ & $0.69 \pm 0.16$ & $0.34 \pm 0.01$ & $1.10 \pm 0.40$ & $0.30 \pm 0.01$ & $0.03 \pm 0.01$ \\
\hline Ciceritol & $0.47 \pm 0.06$ & $3.42 \pm 0.48$ & $1.11 \pm 0.05$ & $1.06 \pm 0.16$ & $0 \pm 0$ & $1.26 \pm 0.17$ \\
\hline Digalacto-myo-inositol & $0.06 \pm 0.02$ & $0.14 \pm 0.01$ & $0.03 \pm 0.01$ & $0 \pm 0$ & $0 \pm 0$ & $0 \pm 0$ \\
\hline Fagopyritol B1 & $0.16 \pm 0.01$ & $0 \pm 0$ & $0 \pm 0$ & $0 \pm 0$ & $0.73 \pm 0.04$ & $0 \pm 0$ \\
\hline Fagopyritol B2 & $0.17 \pm 0.01$ & $0 \pm 0$ & $0 \pm 0$ & $0 \pm 0$ & $0 \pm 0$ & $0 \pm 0$ \\
\hline \multirow[t]{2}{*}{ Trigalactopinitol A } & $0.43 \pm 0.03$ & $2.56 \pm 0.06$ & $0.31 \pm 0.05$ & $0 \pm 0$ & $2.40 \pm 0.23$ & $1.61 \pm 0.12$ \\
\hline & \multicolumn{6}{|c|}{ Raffinose family oligosaccharides } \\
\hline Raffinose & $4.53 \pm 0.25$ & $7.05 \pm 0.12$ & $5.70 \pm 1.52$ & $8.83 \pm 1.12$ & $0.84 \pm 0.14$ & $3.81 \pm 0.45$ \\
\hline Stachyose & $18.57 \pm 0.24$ & $22.06 \pm 1.23$ & $14.01 \pm 0.14$ & $20.41 \pm 2.15$ & $5.09 \pm 0.36$ & $18.01 \pm 1.59$ \\
\hline Verbascose & $6.37 \pm 0.54$ & $6.56 \pm 1.56$ & $3.74 \pm 0.11$ & trace & $26.84 \pm 1.29$ & $8.94 \pm 0.78$ \\
\hline Sum of RFO & 29.48 & 35.67 & 23.46 & 29.24 & 32.76 & 30.75 \\
\hline Sucrose/RFO & 0.09 & 0.71 & 1.05 & 0.77 & 1.05 & 0.22 \\
\hline Sum of soluble carbohydrats & 38.22 & 77.59 & 57.03 & 34.07 & 76.32 & 44.44 \\
\hline Unidentified components & 8 & 6 & 4 & 5 & 8 & 3 \\
\hline
\end{tabular}

The accumulation of compounds representing one galactosyl cyclitol series depended on intense synthesis of a basic cyclitol in a given series. The seeds of Lupinus rotundiflorus contained considerable amounts of both D-pinitol and its galactosyl derivatives (Table 1).

Galactosyl cyclitols are accumulated in the lupin seeds in significant amounts (Piotrowicz-Cieślak et al. 1999), however, the information on the physiological role they play is limited. Galactosyl cyclitols have been found in seeds of various plant species (Horbowicz and Obendorf 1994). These compounds are formed after a cyclitol binds with one or two galactose molecules with the $\alpha-(1 \rightarrow 6)$ and $\alpha$ $-(1 \rightarrow 2)$ or $\alpha-(1 \rightarrow 3)$ galactosyl bond. These compounds may form higher order homological sequences. Among the galactosyl cyclitols, the greatest amount of data has been collected on the galactinol ( 0 - $\alpha$-D-galactopyranosyl$(1 \rightarrow 3)$-D-myo-inositol) that is the carrier of the D-myo-inositol galactosyl residues to sucrose and higher homologic sequences such as the raffinose family sugars (Dey 1990). Galactosyl cyclitols, like the raffinose family oligosaccharides, belong to the basic group of storage compounds present in lupin seeds (Piotrowicz-Cieślak et al. 1999).

Galactosyl cyclitols are being accumulated at the same time as stachyose during the ripening of soybean seeds (Obendorf 1997). Also unripe soybean seeds accumulate galactopinitols during slow drying (Obendorf et al. 1996). This suggests that galactosyl cyclitols may take over or enhance the role of the raffinose family oligosaccharides. In the seeds with no raffinose family oligosaccharides drying tolerance is provided by galactosyl cyclitols. The buckwheat grain drying tolerance is provided by the accumulated fagopyritol (galacto-chiro-inositol) as the main soluble carbohydrate of buckwheat (Obendorf et al. 1993). Also, galactosyl cyclitols in the alf-alfa somatic germs were suggested to play an important role in enhancing the tolerance to drying (Horbowicz et al. 1995). Other Leguminosae seeds including lentil, garden bean, chickpea, pigeon pea, cowpea and underground clover contain amounts of galactosyl cyclitols in the soluble sugars pool (Horbowicz and Obendorf 1994; Obendorf 1997).

\section{Monosaccharides and sucrose}

In the analysed Mexican lupin species seeds only fructose was present. Its amounts were below $0.6 \mathrm{mg} / \mathrm{g}$ d.m. In the seeds of the cultivated lupin species, the presence of glucose or galactose was also found. The presence of the latter sugars proves that the seeds have not yet achieved full physiological maturity. Glucose and galactose are typical for ripening or old seeds (Górecki et al. 1997a). Sucrose is present in all wild lupin seeds, their amounts is 2.7 
$\mathrm{mg} / \mathrm{g}$ d.m. in Lupinus montanus to $34.4 \mathrm{mg} / \mathrm{g}$ d.m. in L. mandrensis. Frequently monosaccharide residues of fructose, glucose and galactose found in mature seeds (Horbowicz et al. 1995; Sun and Leopold 1995). Large amounts of monosaccharides, however, were found in maturing crop lupin seeds (Górecki et al. 1997b).

\section{Cyclitols}

This term refers to polyhydroxylcycloalkanes and their derivatives common in nature (Loewus and Loewus 1980). Nine inositol enanciomers have been identified and distinguished by the position of the hydroxyl group (Loewus 1990). In the analysed seeds, the cyclitols were represented by D-pinitol, D-chiro-inositol and myo-inositol. The D-pinitol was dominant in the Lupinus rotundiflorus seeds, myo-inositol was dominated in Lupinus mexicanus and D-chiro-inositol in Lupinus exaltatus. The cyclitol physiological role in the wild lupin seeds is undoubtedly the same as in the crop lupin seeds. myo-Inositol is the primary source in the cyclitols biosynthesis (Dey 1985). Two paths of D-pinitol formation are proposed. In the first, myo-inositol is methylated with methyltransferase to sequitol (5-o-methylo-myo-inositol) and then transformed during a two-stage epimerisation to pinitol (Kremlicka, Hoffman-Ostenhoff 1966). In the other path, myo-inositol is methylated to D-ononitol from which D-pinitol is formed (Vernon 1993). This transformation is apparently possible due to ononitol dehydrogenase (Obendorf et al. 1993). It is also likely that D-chiro-inositol may be formed as a result of demethylation, but the enzyme participating in this process has not yet been identified (Obendorf 1997).

D-ononitol is present in Simmondsia chinensis, Ononis spinosa, Medicago sativa and Trifolium incarnatum (Dittrich and Brandl 1987). D-chiro-inositol is formed from D-pinitol through demethylation, however, the enzyme catalysing its biosynthesis has not yet been characterised (Obendorf 1997).

\section{ACKNOWLEDGEMENTS}

This work was financially supported by the State Committee for Scientific Research (KBN) grant number 3 P06A 00523.

\section{LITERATURE CITED}

ARENTOFT A.M., SÖRENSEN H. 1992. Alpha galactosides and dietary fibres in relation to pea quality: Methods of oligosaccharides analyses. In: P. Plancquaert (ed.). Proc. of the $1^{\text {st }}$ Conference on Grain Legumes. Anger, France, 457-458.

BUIRCHELL B.J., COWLING W.A. 1992. Domestication of rough-seeded lupins. J. Agric.-West. Aust. (4th series) 33: 131-137.

CHEN Y., BURRIS J.S. 1990. Role of carbohydrates in desiccation tolerance and membrane behavior in maturing maize seed. Crop Sci. 30: 971-975.

CRISTOFARO E., MOTTLI F., WHURMANN J.J. 1974. Involvement of raffinose family of oligosaccharides in flatulence. In: H.L. Sepple, K.W. McNutt (eds), Sugars in Nutrition 313363, New York, Academic Press.

DEY P.M. 1985. D-galactose-containing oligosaccharides. In: P.M. Dey, R.A. Dixon (eds), Biochemistry of storage carbohydrates in green plants. 53-129, Academic Press, London.

DEY P.M. 1990. Oligosaccharides. In: P.M. Dey, J.B. Harbourne (eds), Methods in plant biochemistry. Academic Press Ltd., London.
DITTRICH P., BRANDL A. 1987. Revision of the pathway of d-pinitol formation in Leguminosae. Phytochemistry 26: 1925$-1926$.

FRIAS J., VIDAL-VALVERDE C., KOZŁOWSKA H., GÓRECKI R., HONKE J., HEDLEY C.L. 1996. Evolution of soluble carbohydrates during seed development of pea, faba bean and lupin seeds. Z. Lebensm. Unters. Forsch. 203: 37-22.

GLADSTONES J.S. 1998. Distribution, origin, taxonomy, history and importance. In: J.S. Gladstones, C. Atkins, J. Hamblin (eds), Lupins as crop plants: Biology, production and utilization. CAB International.

GÓRECKI R.J., PIOTROWICZ-CIEŚLAK A.I., LAHUTA L.B., OBENDORF R.L 1997a. Soluble carbohydrates in desiccation tolerance of yellow lupin seeds during maturation and germination. Seed Sci. Res. 7: 107-115.

GÓRECKI R.J., PIOTROWICZ-CIEŚLAK A.I., OBENDORF R.L. 1997b. Soluble sugars and flatulence-producing oligosaccharides in maturing yellow lupin (Lupinus luteus L.) seeds. Seed Sci. Res. 7: 185-193.

GULEWICZ P., CISIOŁKA D., FRIAS J., VIDAL-VELVERDE C., FREJNAGEL S., TROJANOWSKA K., GULEWICZ K. 2000. Simple method of isolation and purification of $\alpha$-galactosides from legumes. J. Agric. Food Chem. 48 (8): 3120-3123.

HARRISON C.J. 1996. The rug-3 locus of pea. Ph. D. thesis, University of East Anglia, UK.

HEDLEY C.L. 2000. Carbohydrate chemistry In Carbohydrates in Grain Legume Seeds. Improving Nutritional Quality and Agronomie Characteristics. CABI Publishing UK.

HORBOWICZ M., OBENDORF R.L. 1994. Seed desiccation tolerance and storability: dependence on flatulence-producing oligosaccharides and cyclitols - review and survey. Seed Sci. Res. 4: 385-405.

HORBOWICZ M., OBENDORF R.L., MEKERSIE B.D., VIANDS D.R. 1995. Soluble saccharides and cyclitols in alfalfa (Medicago sativa L.) somatic embryos, leaflets, and mature seeds. Plant Sci. 109: 191-198.

KREMLICKA G.J., HOFFMAN-OSTENHOFF O. 1966. Biosynthesis of cyclitols. Reduction of 5-0-methyl - myo-inosose-(3) by the enzyme of Trifolium incarnatum. Hoppe-Seyler's Z. Physiol. Chem. 344: 261-266.

KUO T.M., VANMIDDLESWORTH J.F., WOLF W.J. 1988. Content of raffinose oligosaccharides and sucrose in various plant seeds. J. Agric. Food Chem. 36: 32-36.

KVASNIČKA F., AHMADOVÁ-VAVROUSOVÁ R., MRSKOŠ M., VELÍŠEK J., KADLEC P. 1994. Characteristics of pea varieties according to galactooligosaccharides content. Agrifood quality: An interdisciplinary approach, 153-156.

LAHUTA L.B., GOJŁO E., GÓRECKI R.J. 2002. Accumulation of $\alpha$-D-galactosides of sucrose and D-pinitol in developing seeds of Vicia hirsuta L. S.F. Gray during desiccation. Adv. Agric. Sci. Probl. 481 235-242.

LARSSON S., JOHANSSON L.A., SVENNINGSSON M. 1993. Soluble sugars and membrane lipids in winter wheats (Triticum aestivum L.) during cold acclimation. Eur. J. Agron. 1: 85-90.

LOEWUS F., LOEWUS M. 1980. Biochemistry of myo-inositol. In: P. Stumpf, E. Conn (eds), Biochemistry of Plants, Vol. 3, Academic Press, New York, N.Y.

LOEWUS F.A. 1990. Cyclitols. In: P.M. Dey, J.B. Harbourne (eds), Methods in Plant Biochemistry, Academic Press, London.

VAN LOO J. CUMMINGS J., DELZENNE N., ENGLYST H., FRANCK A., HOPKINS M., KOK N., MACFARLANE G., NEWTON D., QUIGLEY M., ROBERFROID M., VAN VLIET T., VAN DE HEUVEL E. 1997. Functional food properties of non digestible oligosaccharides: a consensus report from ENDO project (DG XII AIRII-CT94-1095). Br. J. Nutrition 81: 121-132.

LOWELL C.A., KUO T.M. 1989. Oligosaccharide metabolism and accumulation in developing soybean seeds. Crop Sci. 29: 459-465. 
MUZQUIZ M., BURBANO C., PEDROSA M.M., FOLKMAN W., GULEWICZ K. 1999. Lupins as a potential source of raffinose oligosaccharides. Preparative method of their isolation and purification. Industrial Crop and Products 19: 183-188.

OBENDORF R.L. 1997. Oligosaccharides and galactosyl cyclitols in seed desiccation tolerance. Seed Sci. Res. 7: 63-74.

OBENDORF R.L., HORBOWICZ M., TAYLOR D.P. 1993. Structure and chemical composition of developing buckwheat seed. In: J. Janick, J.E. Simon (eds), New crops. New York, John Wiley\&Sons, pp 244-251.

OBENDORF R.L., MOON H., HILDEBRAND D.F., TORISKY R., COLLINS G.B. 1996. A comparsion of pinitols in somatic and zygotic soybean embryos (Abstract). Molecular and Cellular Biology of the Soybean 6: 40.

PETTERSON D.S., SIPSAS S., MACKINTOSH J.B. 1994. The chemical composition and nutritive value of Australian grain legumes. Grain Research and Development Corporation, (2 $2^{\text {nd }}$ edition) Canberra, Australia.

PIOTROWICZ-CIEŚLAK A.I., MICHALCZYK D.J., GÓRECKI R.J., REJOWSKI A. 1998. Oligosaccharides and galactosyl cyclitols during the loss of desiccation tolerance of germination narrow-leaved lupin seeds. Hotriculture and Vegetable Growing 17 (3): 281-289.
PIOTROWICZ-CIEŚLAK A.I., GÓRECKI R.J., ADOMAS B. 1999. The content and composition of soluble carbohydrates in lupin seeds of different species and cultivars. Plant Breading and Seed Sci. 43 (2): 25-34.

PIOTROWICZ-CIEŚLAK A.I., GÓRECKI R.J. 2000. Cyclitols, galactosyl cyclitols and raffinose family oligosaccharides in relation to desiccation tolerance of yellow lupin seedlings. Lupin an Ancient Crop for the New Millenium, E. van Santen, M. Wink, S. Weissmann, P. Romer (eds). 366-370.

PIOTROWICZ-CIEŚLAK A.I. 2002. The effect of temperature stress on the content of soluble sugars and physical quality of mature yellow lupin seeds. Adv. Agric. Sci. Problem, 481: 205-211.

SAINI H.S., GLADSTONES J.S. 1986. Variability in the total and component galactosyl sucrose oligosaccharides of Lupinus species. Aust. J. Agric. Res. 37: 57-166.

SUN W.Q., LEOPOLD A.C. 1995. The Maillard reaction and oxidative stress during aging of soybean seeds. Physiol. Plant. 94: 94-104.

TOMOMATSU H. 1994. Health effects of oligosaccharides. Food Technol. 48: 61-65.

VERNON D.M., TARCZYNSKI M.C., JENSEN R.G., BOHNERT H.J. 1993. Cyclitol production in transgenic tobacco. Plant J. 4: 199-205.

\title{
CYKLITOLE, GALAKTOZYLOCYKLITOLE I OLIGOSACHARYDY RODZINY RAFINOZY W NASIONACH ŁUBINÓW DZIKO ROSNĄCYCH W MEKSYKU
}

\section{STRESZCZENIE}

\begin{abstract}
Zidentyfikowano w nasionach sześciu dzikich gatunków łubinów rosnących w Meksyku od dziesięciu do 16 węglowodanów rozpuszczalnych w etanolu. Analizowane węglowodany obejmowały: monosacharydy, dwucukry, cyklitole, galaktozylocyklitole i oligosacharydy rodziny rafinozy. Stachioza i sacharoza były zasadniczymi węglowodanami rozpuszczalnymi w nasionach Lupinus montanus, L. rotundiflorus, L. exaltatus, L. mexicanus i $L$. elegans. Werbaskoza wystepowała w sladowych ilościach w nasionach Lupinus mexicanus. Analizowane nasiona gromadziły od 38 do $78 \mathrm{mg} / \mathrm{g}$ suchej masy węglowodanów. Zasadniczym komponentem węglowodanowym były oligosacharydy rodziny rafinozy obejmujące od 41 do $85,2 \%$ puli zidentyfikowanych węglowodanów. Analizowane nasiona rodzaju Lupinus zawierały 3 do 8 niezidentyfikowanych składników węglowodanowych.
\end{abstract}

SŁOWA KLUCZOWE: nasiona łubinów dzikich, węglowodany, oligosacharydy rodziny rafinozy, galaktozylocyklitole, cyklitole. 